Marcin Kotras*

\title{
BADACZ W SAMORZĄDZIE, CZYLI CO DOSTAJEMY BADAJĄC POLITYKÓW
}

W dobie demokracji sondażowej badania dotyczące sfery polityki kojarzą się zwykle z sondażami prezentującymi poparcie dla partii politycznych i poszczególnych polityków. Multiplikowanie wykresów i prezentacji graficznych, z których widz-odbiorca dowiaduje się (przynajmniej w założeniu i domyśle nadawcy), jak wygląda rozkład poparcia dla poszczególnych partii politycznych i sympatia dla aktorów politycznych, zyskało właściwie formę rytuału współczesnych serwisów informacyjnych. Towarzyszy temu ukryte założenie, że ta zestandaryzowana i kwantyfikowana „wiedza” zbliża nas do poprawnego opisu współczesnego, wysoce rywalizacyjnego pola polityki. Dominacja w mediach tego typu podejścia badawczego nie oznacza oczywiście, że inne podejście metodologiczne, koncentrujące się na metodach jakościowych, nie może być użyteczne w badaniu zjawisk z gruntu polityki. Jednak tego typu refleksja i analizy prezentowane są masowemu odbiorcy dużo rzadziej. Być może dynamiczny rozwój tych metod i coraz powszechniejsze ich stosowanie $\mathrm{w}$ badaniach dotyczących zagadnień ze sfery, np. socjologii polityki, pozwolą na ich częstszą obecność również w przekazach masowych. Do jednego z ciekawszych nurtów można zaliczyć badania odwołujące się do problemu społecznych reprezentacji polityki, odtwarzania sposobu budowania języka polityki lub komunikacji politycznej w oparciu o źródła niewywołane, analizy przekazów masowych, analizy konwersacyjne i analizy wizualne (Czyżewski, Kowalski, Pi o trowski, red. 2010). Wciąż jednak mniej jest badań opierających się na źródłach wywołanych, powstających w wyniku rozmowy (bezpośredniej interakcji) badacza z politykiem. Dzięki stosowaniu metod jakościowych, możliwe, choć wcale nie łatwiejsze, staje się docieranie do tematów trudnych, wymagających od rozmówcy większej refleksji, zagłębienia się w analizowane kwestie. Jak się jednak okazuje, trudnym tematem może być sama rozmowa o polityce, o tym czym ona jest, jak się ją uprawia, jak definiuje się w niej swoją rolę. Inne kwestie „drażliwe” to ocena kolegów, tych z własnej partii i tych $\mathrm{z}$ opozycji, ocena wyborców i instytucji, w której wykonuje się swą pracę

\footnotetext{
* Dr, adiunkt, socjolog polityki, Katedra Socjologii Polityki i Moralności, Instytut Socjologii, Uniwersytet Łódzki, ul. Rewolucji 1905 r. 39/41, 90-214 Łódź; kotras@o2.pl.
} 
bądź wypełnia mandat. Trudne, choć jest to trudność innego rodzaju, są również w trakcie wywiadów tzw. pytania o wiedzę. Innymi słowy, jak w najmniej inwazyjny sposób spróbować odtworzyć na podstawie wypowiedzi polityka jego faktyczne kompetencje, znajomość przypisanych mu prerogatyw czy założenia realizowanych w danej instytucji programów. Do tych problemów odnosi się ten artykuł, w którym zostaną one omówione na przykładzie jednego z badań przeprowadzonych w Sejmiku Województwa Łódzkiego drugiej kadencji (2002-2006). Na początku warto jednak wskazać na pewne ustalenia o charakterze ogólnym.

Jednym z kluczowych problemów dla badacza polityki jest uwzględnienie kwestii związanych z ramami funkcjonowania systemu politycznego. Warto o tym pamiętać przy ustalaniu problematyki badania, konstrukcji wstępnych założeń i przy stawianiu hipotez. Pozwala to badaczowi na uniknięcie jednego z podstawowych błędów w myśleniu politycznym, który Janusz Reykowski nazywa „błędem centracji” (R e y k o w s k i 1999). Chodzi mu o definiowanie i opis zjawisk politycznych w oparciu o jedną przyczynę. Dlatego ważne jest uwzględnienie uwarunkowań systemowych, choćby tych odnoszących się do scenariusza roli wybieralnego polityka i charakteru reżimu. Mam tu na myśli głównie kategorię tzw. demokracji przedstawicielskiej, stosowaną do opisu istniejącego systemu. Zakłada ona, że obywatele w demokratycznych organach władzy reprezentowani są przez wybieranych przez siebie przedstawicieli. Należy jednak pamiętać, że wybrana osoba realizuje otrzymany w wyborach mandat na zasadach wolnych, inaczej mówiąc mandat ten nie ma charakteru imperatywnego, a polityk (poseł, radny) nie jest związany wizją wyborów. Oznacza to, że wypełnia on swój mandat zgodnie ze swoją wolą i przeświadczeniem, co do tego, jak należy to robić. W praktyce nie oznacza to naturalnie, że zapomina on o swoim okręgu wyborczym. Takie zachowanie byłoby nieracjonalne z punktu widzenia kolejnych wyborów, gdzie przynajmniej część wyborców dokonuje rozliczeń kandydata na podstawie tego, co zrobił dla tych, w imieniu których zasiada jako reprezentant w danej instytucji. Problemy te były bardzo dobrze widoczne w prowadzonych przeze mnie badaniach. Przykładem tego mogą być cytaty:

Osoba taka przede wszystkim powinna się utożsamiać z regionem, po drugie z tym okręgiem, z którego pochodzi, pamiętać o tym, że trzeba się spotykać z mieszkańcami, bo dość często ci, którzy są wybrani na stanowiska, o tym zapominają [...] Musi żyć, musi żyć po prostu tym, co się dzieje na terenie $[\mathrm{R} 14]^{1}$;

Jeżeli ktokolwiek się do mnie zwraca, wiadomo, że przede wszystkim koszula zawsze jest bliższa ciału, czyli z mojego okręgu wyborczego, ale jestem radnym województwa łódzkiego, podkreślam. To, jeżeli coś jest w moich możliwościach, moich gestiach, moich kompetencjach, to zawsze chcę pomóc, a nie odmawiam [R10];

1 W podanym zapisie litera R oznacza rozmówcę, liczby zaś były przyporządkowane kolejnym rozmówcom (mają one jedynie znaczenie porządkowe i służą ,zakodowaniu” rozmówców). Nagrania z przeprowadzonych wywiadów oraz ich transkrypcja znajdują się w archiwum autora. 
Dlatego jednak, że każdy z nas w pierwszej kolejności oczywiście chce zrobić coś dobrego dla całego regionu, no ale przecież zawsze będzie pamiętał o tym, że jednak wybierają go konkretni ludzie. I to właśnie ci ludzie, to oni zadają radnemu po czterech latach pytanie, no dobrze masz piękne wizje i piękne plany, ale co zrobiłeś dla nas? I o tym każdy z radnych musi pamiętać [R12].

Opisując swoją rolę, politycy dystansowali się od jej formalnego (ustawowego) wymiaru, zaś akcentowali jej służebny charakter wobec wyborców z ich okręgów (wtedy też starali się dystansować od określania ich mianem polityków lub przywódców politycznych, o czym będzie jeszcze niżej w tekście).

Ważne jest więc, aby pamiętać, że przystępując do badania musimy być świadomi formalnych i nieformalnych (kulturowych) ograniczeń, jakie stawiają przed politykiem nadawcy jego roli społecznej. Dla badacza interesujący powinien być zarówno jeden, jak i drugi wymiar. Politycy wydają się świadomi tego, że oprócz legitymizacji ich władzy na poziomie reguł, liczą się również: poziom przekonań dotyczący wspólnych punktów widzenia rządzących i rządzonych oraz poziom zachowań wyrażany przez czynne przyzwolenie rządzonych (wyborców) na sprawowanie władzy przez określone grupy (partie, elity) (por. B e e th a m 1995).

Badacz posługujący się technikami jakościowymi, np. wywiadem swobodnym, w relacji ze swym rozmówcą-badanym występuje w wielu rolach. Jest badaczem-ekspertem, specjalizującym się w danej dziedzinie (np. socjologii polityki) i znającym modelowe założenia związane ze sposobem i logiką funkcjonowania instytucji politycznych (np. sejmiku województwa). Jest badaczem-partnerem dla swego rozmówcy (np. radnego) próbującym zbudować relację opartą na zaufaniu (służyć ma to również uzyskaniu od badanego wiarygodnych informacji). Inną rolą jest ta, którą można określić jako badacz-wyborca, przy czym relacja ta ma dwustronny charakter. $Z$ jednej strony badacz dowiaduje się „,czegoś” o aktorach politycznych, z drugiej strony polityk stara się wywrzeć określone wrażenie na badaczu (być może na jego potencjalnym wyborcy, multiplikatorze opinii, a na pewno na kimś, kto będzie publikował, upubliczniał informacje na temat jego lub jej działania albo instytucji, w której dany polityk pełni mandat, pracuje). To kolejna uwaga, a jednocześnie postulat, aby starać się pozostawić swój subiektywny świat przekonań politycznych ,za drzwiami”, za którymi odbywać się będzie rozmowa. Nie oznacza to naturalnie, że wnioski, jakie wyciągamy z danego badania mają być wolne od naszej krytycznej interpretacji. Badacze zajmujący się metodami jakościowymi w naukach społecznych, jak np. Norman K. Denzin, zwracają uwagę, że istotą tych badań jest interpretacja, jakiej dokonuje badacz w oparciu o zebrany materiał. Ważne jest wtedy, aby nie przenosić na grunt owej interpretacji subiektywnego świata badacza, zwłaszcza jeśli obecne są w nim pewne stereotypy, kategoryzacje i uprzedzenia. Istotne jest ponadto, aby wystrzegać się ,prawidłowego odtwarzania rzeczywistości”, co widoczne jest wtedy, gdy posługujemy się kliszami językowymi do opisu badanej rzeczywistości. 
Starałem się w swoich badaniach unikać prezentowania siebie jako potencjalnego wyborcy, choć nie da się uniknąć niekiedy machinalnego przytakiwania naszemu rozmówcy nawet wtedy, kiedy mówi o czymś, co dalekie jest od naszej wizji świata. Przyjąłem formułę badacza tabula rasa, który nastawia się głównie na odbiór informacji od swojego rozmówcy. W niektórych momentach wywiadu, np. kiedy rozmowa dotyczyła kwestii budżetu województwa bądź przyszłych scenariuszy integracyjnych (np. Europy regionów), starałem się jednak pokazywać swoje przygotowanie do rozmowy posługując się tzw. profesjonalnym żargonem, licząc na dopasowanie werbalne ze strony rozmówców. Ponadto w rozmowach nie ujawniałem swych własnych poglądów i nie pytali o nie również moi rozmówcy (raz, jeden z rozmówców zapytał, co sądzę o algorytmie stosowanym $\mathrm{w}$ polityce regionalnej przy wyliczaniu środków). Pytając używałem formuł: „Czytając na ten temat natrafiłem na pogląd, który wydaje się sprzeczny z tym, co Pan mówi” albo „W oczach innych osób to, co Pan mówi, może być kontrowersyjne”. Stosowałem też „podręcznikowe” sformułowania w postaci: „to bardzo interesujące, co Pan mówi, czy mógłby Pan skomentować teraz...”, „ta opinia jest dla mnie ważna, czy dobrze zrozumiałem, że...". Nie chciałem, aby rozmowa przybrała styl konfrontacyjny, nie chciałem też, żeby moje poglądy wpływały na ocenę rozmówców i ich traktowanie w momencie wywiadu. Brzmi to może, jak z podręczników poświęconych asertywności, ale starałem się oddzielać rolę od osoby, a przy tym samemu starałem się zachowywać profesjonalnie. Ponadto charakterystyczne jest to, że kiedy pytałem radnych o efekty ich pracy jako grupy, całej instytucji, byli oni zdecydowanie bardziej krytyczni w ocenach (np. kiedy dotyczyły one strategii rozwoju województwa) niż wtedy, kiedy odnosili się do swej własnej pracy i osiągnięć.

Badanie zjawisk politycznych, w tym samych aktorów-polityków, jak wspomniałem wyżej, nie jest zadaniem łatwym. Ciekawe w kontekście tego typu badań okazują się rozważania, dotyczące badań jakościowych i ich prowadzenia, jako metafory kolonialnej wiedzy, władzy i prawdy (D e n z in, L in c o ln 2010: 19). W moim przekonaniu badanie polityki ma w sobie coś z badania obcego, nieznanego świata. Świata, w który badacz-ekspert wkracza jako ,wiedzący” (depozytariusz wiedzy) - wie, jak być powinno, zaś otrzymane dane traktować może jako obraz świata odbiegającego od „właściwych praktyk” i sposobów zachowań. Pokusa stosunku do polityki i polityków jest silna. Zwłaszcza dziś, gdzie w różnych formach dyskursu - od naukowego po publicystyczny - polityka sprowadzona została do formuly politics, czyli rywalizacyjnego pola, gdzie aktorzy, podmioty polityczne (partie, grupy nacisku) konkurują o władzę lub, jak chce Joseph A. S c h u m p e te r (2009), o „moc decydowania” przyznawaną przez wyborców. Ponadto w zgodzie z mediatyzacją i personalizacją polityki, w mediach eksponowany jest głównie poziom centralny z silnie spolaryzowanym (choć to $\mathrm{w}$ wielu punktach polityczny teatr) środowiskiem partyjnym. 
Nie bez powodu kwestię tę uważam za rzecz zasadniczą. Protekcjonalny stosunek do rozmówcy, odpytywanie go i dogłębne sprawdzanie jej lub jego wiedzy niekiedy po to, by wykazać politykowi niekonsekwencję bądź niespójność postawy jest poważnym błędem. Taka badawcza strategia może bardzo szybko zakończyć nie tylko prowadzony wywiad, ale całe badania w danej instytucji. Nasze krytyczne uwagi, oceniające spostrzeżenia, powinniśmy (jeśli uznamy to za koniecznie) przenieść do raportu sporządzanego po badaniach. Zdaję sobie sprawę, że nie jest to proste. Coraz trudniej jest zachować badawczą wstrzemięźliwość i realizować szlachetny, XIX-wieczny ideał pozytywistycznego badacza, który nie ingeruje, a jedynie stara się ze zrozumieniem przyglądać badanemu zjawisku z boku. W każdym z wywiadów starałem się jednak ukrywać własne poglądy polityczne. Nie uważałem bowiem za celowe prowadzenie polemiki z moim rozmówcą, zaś głównym celem była próba odtworzenia tego, jak swoją rolę postrzegają badani. Naturalnie nie mam też na myśli podejścia graniczącego z naiwnością, gdy to, co mówią badani traktuję w pełni jako rzetelną i jedyną informację, na podstawie której jestem w stanie odtworzyć ich styl działania, poglądy i postrzeganie roli polityka.

Warto zwrócić uwagę na dylematy dotyczące etyki prowadzonych badań, które także dotyczą kwestii fundamentalnych. Czy badanie ma służyć jedynie opisowi zastanej rzeczywistości, czy powinno być punktem wyjścia do wprowadzanych zmian, niekiedy z aktywnym udziałem badacza? Jest to dylemat, który trudno jest jednoznacznie rozstrzygnąć. Jaka jest rola socjologa-badacza: czy ma on jedynie zdać raport z istniejącego stanu rzeczy (i liczyć np. na aktywność badanej grupy, która będzie chciała na tej podstawie dążyć do zmiany aktualnej sytuacji), czy ma również włączać się w sposób aktywny w działanie danej zbiorowości, angażować się w określone przedsięwzięcia, wskazywać konkretnym aktorom konieczne w jego opinii kierunki zmian?

Odpowiedź na to pytanie w dużej mierze zależy od celu badań, kompetencji i pozycji badacza oraz instytucjonalnych możliwości wprowadzenia zmian. W opisywanych w artykule badaniach nie zdecydowałem się na bezpośrednią ingerencję w badaną zbiorowość, koncentrując się na raporcie, gdzie wskazałem kilka - mym zdaniem - ważnych elementów wymagających przynajmniej namysłu i refleksji od lokalnych polityków. Problem jednak w tej sytuacji polega również na tym, że zbiorowość radnych nie jest grupą o ustabilizowanym składzie. Zachodzi w niej znaczna rotacja związana z cyklami wyborczymi.

Jednym z kluczowych problemów jest wejście do świata badanych, do tworzonych przez nich organizacji i sieci relacji. Każdy proces badawczy oprócz angażowania czasu badacza i kosztów materialnych wiąże się często z zaangażowaniem osobistych uczuć i relacji. Nie musi być to konieczne i zamierzone. Może do tego dojść niejako „przy okazji” badania. Trudno jednak założyć, że w sytuacji kiedy chcemy zbudować określoną więź z naszym rozmówcą możemy pozostać 
zupełnie obojętni. Wreszcie, jak „podejść” do naszego rozmówcy, jeśli wiemy, że reprezentuje on zupełnie odmienne poglądy od naszych albo reprezentuje środowisko polityczne zupełnie nam obce lub wrogie. Do tego typu refleksji zachęca Kirsten Hastrup ${ }^{2}$ pytając, jak badacz postrzega rolę rozmówcy w badaniu. Na ile wolno nam wyrażać swe własne emocje i ujawniać ich treść przed badanym, czy liczymy, że jedynie druga strona będzie tą, która ma cokolwiek uzewnętrzniać? Czy nasza relacja z badanym ma charakter instrumentalny, pasożytniczy i eksploatacyjny? Czy w relacji tej mamy do czynienia z asymetrią, gdzie to badacz występuje z pozycji autorytetu (decydując się niekiedy na stosowanie przemocy symbolicznej i językowej)? Jak radzić sobie w tego typu sytuacjach z czymś, co Hastrup umieszcza pośród problemów natury heurystycznej (te rozważania Hastrup podaję za: Wy k a 1993: 157-160)? Pisze ona o tzw. podwójnej lojalności, gdzie z jednej strony jako badacze winni jesteśmy lojalności wobec szeroko rozumianej nauki (zarówno w sferze episteme, jak i techne z wyłączeniem doksy), z drugiej zaś strony, lojalności oczekiwać może od nas badany obdarzający nas przecież (przynajmniej w ograniczonym stopniu) zaufaniem.

Również w moich badaniach owo wejście do badanego środowiska było jednym z najważniejszych elementów. Środowisko lokalnych polityków jest dość hermetyczne. To ludzie znający się nawzajem, pracujący z reguły wcześniej na różnych szczeblach samorządu lub wywodzący się ze środowisk partyjnych. Ponadto podobnie, jak scenę centralną, również poziom regionu charakteryzują podziały partyjne (jak i te wewnątrzpartyjne) istniejące w tego typu instytucjach. Jest to obok innych czynników efekt obowiązującej przy wyborach do sejmiku ordynacji wyborczej, przypominającej tę używaną w wyborach do Sejmu. Wyborcy oddają tzw. głos preferowany, czyli w pierwszej kolejności głosują niejako na listę, zaś w drugiej wskazują komu z tej listy chcieliby powierzyć mandat radnego. Takie rozwiązanie (oraz dodatkowo układ okręgów wyborczych) preferuje komitety wyborczy związane z silnymi, ogólnokrajowymi i bogatymi partiami politycznymi (można to zweryfikować obserwując, jakie komitety partyjne zdobywały mandaty wyborcze w 2002, 2006 i 2010 r.).

W dotarciu do radnych pomocne okazało się nawiązanie kontaktu ze służbami prasowymi sejmiku, w szczególności zaś z rzeczniczką prasową. Osoby te coraz częściej i coraz lepiej rozumieją konieczność rozbudowywania środowiska informacyjnego tego typu instytucji oraz kwestię otwartości komunikacyjnej. Pomogło mi, że przed rozpoczęciem wywiadów z politykami byłem przedstawiany przez rzeczniczkę poszczególnym radnym sejmiku. Nie byłem po tym dla nich osobą całkowicie anonimową, „kimś z zewnątrz”. Znali założenia badania, czego ono dotyczy, jak wykorzystane będą wyniki i jaką reprezentuję instytucję, widzieli, że przysłuchiwałem się obradom na sali. To, czego obawiałem się przystępując do badań, to bycia postrzeganym jako osoba, która przychodzi do sejmiku

2 Chodzi głównie o dwa opracowania tej autorki: H a s tr u p 1987, 1992. 
w charakterze recenzenta, osoby przepytującej radnych i szukającej słabych stron ich pracy. Starałem się więc unikać zachowań i komentarzy, pokazujących moją stronniczość bądź dezaprobatę np. w stosunku do wypowiedzi lub argumentacji poszczególnych radnych.

$\mathrm{Na}$ wszystkie wywiady umawiałem się osobiście przychodząc do siedziby Urzędu Marszałkowskiego w Łodzi. Najczęściej były to dni, kiedy odbywały się sesje sejmiku wojewódzkiego lub też przychodziłem na dyżury radnych, niekiedy w godzinach urzędowania członków zarządu. Pomocą w przeprowadzeniu wywiadów służyła mi rzecznika sejmiku. Udostępniła mi potrzebne informacje, takie jak np. grafik posiedzeń komisji, terminy planowanych sesji, służyła również pomocą w dotarciu do radnych. Przed rozpoczęciem badania rozesłałem listy wyjaśniające cel prowadzonego badania, w których prosiłem o udzielenie mi pomocy (adresatami była kancelaria sejmiku wojewódzkiego oraz rzecznicy prasowi sejmiku i marszałka województwa). Trudniejszy kontakt był z niektórymi członkami zarządu województwa, w tym niestety z marszałkiem województwa. Miałem jednak wrażenie, że niektórzy radni odebrali chęć rozmowy z nimi jako próbę sprawdzenia ich kompetencji, ocenę pracy na zajmowanym przez nich stanowisku. Każdy z radnych godzący się na wywiad, zgadzał się również na nagrywanie rozmowy.

Łącznie miałem cztery odmowy przeprowadzenia wywiadu. Wszyscy podali taki sam powód, a mianowicie brak czasu i napięty harmonogram zajęć. Dwie osoby (i są to członkowie zarządu) zgodzili się na wypełnienie ankiety dotyczącej zagadnień poruszanych przeze mnie w trakcie wywiadów. W dwóch przypadkach można mówić również o istotnym zakłóceniu sytuacji wywiadu: w pierwszym z nich jeden z radnych prosił o obecność rzeczniczki sejmiku w trakcie rozmowy, w drugim - podczas prowadzenia przeze mnie wywiadu do pokoju wszedł inny radny $z$ tego ugrupowania i włączył się do rozmowy.

Wywiady z radnymi zostały przeprowadzone (za wyjątkiem dwóch) w siedzibie Urzędu Marszałkowskiego, gdzie znajduje się również sejmik wojewódzki. Przeprowadzenie wywiadów poprzedzone zostało przesłaniem pism wprowadzających do kancelarii sejmiku wojewódzkiego oraz rozmową z rzeczniczką prasową sejmiku i rzecznikiem prasowym marszałka. W trakcie prowadzenia badań uczestniczyłem również jako widz/obserwator w sesjach sejmiku wojewódzkiego (w obradach jako obserwator uczestniczyć może każdy obywatel) oraz w jednym posiedzeniu komisji sejmiku (o mojej obecności na tym spotkaniu radni zostali poinformowani przez rzeczniczkę sejmiku). Obecność na sesjach i w trakcie posiedzenia komisji pozwoliła mi na zaobserwowanie zachowania poszczególnych radnych w trakcie wykonywania przez nich obowiązków. Nie będzie to niczym zaskakującym, jeśli dodam, że temperatura obrad i prowadzonych dyskusji wzrastała wtedy, kiedy na sali obrad pojawiali się dziennikarze telewizyjni i radiowi, oraz w sytuacji, gdy dyskutowano o sprawach personalnych (obsada stanowisk np. w komisjach sejmiku i instytucjach podległych sejmikowi). 
Struktura wywiadu miała charakter elastyczny i modyfikowana była wraz z przygotowywaniem koncepcji badania i kształtu wywiadu (R u bi n, R ubin 1997). Punktem wyjścia był wywiad swobodny ze standaryzowaną listą poszukiwanych informacji. Jest to typ wywiadu zaproponowany przez Ilonę Przybyłowską (Przybyłowska 1978). Jego zaletą jest możliwość statystycznej weryfikacji hipotez. Pozwala on jednocześnie wyjść poza sztywne ramy wywiadu kwestionariuszowego z ustalonymi z góry pytaniami. Możliwy jest dzięki temu mniej formalny kontakt badacza $\mathrm{z}$ respondentem, zbliżony choćby w części do sytuacji rozmowy. W przypadku tego wywiadu ankieter (badacz) nie posiada stałej, jednobrzmiącej listy pytań, które zadaje poszczególnym ankietowanym. Jest on natomiast poinstruowany, co do informacji, jakie ma uzyskać w trakcie badania. Pytania mogą być przez ankietera formułowane dowolnie, w dowolnej kolejności. Tempo i kształt wywiadu mają być dostosowane do respondenta. Obowiązkiem prowadzącego wywiad jest uzyskanie ujednoliconych danych, które pozwolą na ich liczbowe i statystyczne opracowanie. W trakcie przygotowywania się do prowadzenia wywiadu stwierdziłem, że nie jest możliwe i w gruncie rzeczy nie jest konieczne, aby trzymać się metodologicznych założeń dotyczących wywiadu ze standaryzowaną listą poszukiwanych informacji. Ze względu na niewielką liczebność zbiorowości, wśród której prowadziłem badania, przeprowadzenia analiz statystycznych wydawało mi się mało zasadne. Ponadto w fazie konceptualizacji badania doszedłem do wniosku, że informacje, jakie chcę uzyskać, i kategorie, jakie chcę badać, mają charakter niezwykle rozległy i wielowątkowy. Niewłaściwa wydała mi się wtedy próba przygotowanej standaryzowanej listy poszukiwanych informacji. Nie chciałem w ten sposób ograniczać moich respondentów. Pierwsza ze sformułowanych dyrektyw metodologicznych przez zespół badaczy, opracowujący wspomnianą metodę, wskazuje na konieczność skonstruowania zamkniętej listy poszukiwanych informacji. Zadaniem ankietera byłoby uzyskanie wszystkich i tylko tych informacji. Wreszcie charakter instytucji, jaką jest sejmik, a dokładnie niewielka zbiorowość radnych i duże jej zróżnicowanie (kompetencyjne, polityczne) stwarzały problemy w realizowaniu badania za pomocą wywiadu ze standaryzowaną listą poszukiwanych informacji.

Dlatego też zdecydowałem, iż lepszym rozwiązaniem będzie zastosowanie $\mathrm{w}$ trakcie badania wywiadu swobodnego z listą poszukiwanych informacji. Najogólniej przyjmując, wywiad swobodny jest rozmową z respondentem prowadzoną bez formularza z pytaniami. Może mieć formę ukierunkowaną (przyjęta w moim przypadku) lub nieukierunkowaną. Formuła wywiadu ukierunkowanego zakłada większą wiedzę wstępną badacza. Jest on w stanie sformułować szczegółowe pytania, jakie w trakcie wywiadu powinny paść. Narzędziem badacza w tym przypadku staje się lista dyspozycji do wywiadu. Przed wywiadem nieukierunkowanym badacz posiada jedynie ogólne wytyczne i pytania problemowe o ogólnym charakterze. Narzędziem dla badacza jest ramowy plan zagadnień. Tego rodzaju wywiad cechuje słaba konceptualizacja. 
Używając metaforycznych kategorii zaproponowanych przez Steinara Kvale: górnika i podróżnika, można przyjąć, że w swoich wywiadach reprezentowałem to pierwsze podejście, jednak niekiedy ze względu na styl prowadzonej rozmowy konieczna była druga perspektywa. Badacz-górnik skupia się na wydobyciu od badanego interesujących go informacji, podczas gdy podróżnik stara się odnaleźć poszukiwane informacje w snutej przez badanego historii. Wiele zależy od umiejętności stawiania odpowiednich pytań przez badacza, przez co może on kierować sytuacją wywiadu, modyfikować go, aby prowadził do uzyskania pożądanych informacji. Zdaniem Kvale, procedura badawcza zakłada: wybór tematu, zaprojektowanie badania, przeprowadzenie wywiadu, transkrypcję, analizę, weryfikację oraz przygotowanie raportu badawczego (K v a le 1996).

Odnosząc się do definiowania wywiadu, należy zauważyć, że głównym celem wywiadu jest zrozumienie znaczenia tego, co mówi osoba, z którą rozmawiamy. Badaczowi, który realizuje badania jakościowe posługując się wywiadem jakościowym, zależy nie tylko na dotarciu do faktów, ale również chce dotrzeć do ich znaczenia, choć to drugie zadanie jest trudne. Wywiady mogą być w tej sytuacji szczególne przydatne, gdyż w pewnej mierze pozwalają one badaczowi wydobyć znaczenie określonych faktów na podstawie relacji osoby udzielającej wywiadu. Kluczowe jest w tym przypadku dotarcie do jej osobistych doświadczeń (P a t t o n 2002). Formuła wywiadu swobodnego pozwala respondentowi na swobodne zachowanie w trakcie rozmowy, dopytywanie. Jest to niezwykle istotne, jeśli badaczowi zależy na opiniach i wrażeniach respondenta. Warto odwoływać się np. do drogi, jaką przebył dany polityk do zajmowanego obecnie stanowiska. W moich wywiadach radni chętnie opowiadali o tym, jak doszło do tego, że stali się radnymi, choć i tu nie opierali się pokusie pozytywnej autoprezentacji.

W wywiadzie swobodnym zadawane są takie pytania, które wynikają ze sposobu rozwijania się rozmowy. Powinny one odnosić się do założonych wcześniej dyspozycji do wywiadu, ale ich treść, kolejność powinny być uzależnione od tempa i kontekstu prowadzonej rozmowy. W ten sposób wywiad przybiera swoisty rytm, który praktycznie zależy od respondenta. Zresztą o tym, jakim ktoś jest radnym, możemy wnioskować na podstawie opisu jego pracy, stosunku do regionu i dotychczasowych osiągnięć, tworząc w ten sposób charakteryzujący go katalog cech.

Dyspozycje do wywiadu przygotowane na poziomie koncepcji badań zakładają pewne pola tematyczne, sugerujące, jakich informacji i danych badacz będzie poszukiwał w trakcie wywiadu. Zakłada to w większym stopniu ukierunkowanie wywiadu na pozyskanie odpowiednich materiałów, ale nie ogranicza w znacznym stopniu swobody respondenta. W omawianych wyżej przypadkach pytania mają charakter otwarty.

Trudną sytuacją w procesie badawczym - i nie dotyczy to jedynie pola badań jakościowych czy wywiadów swobodnych - jest bagaż doświadczeń, wiedzy 
i subiektywna wizja świata badacza. Zaliczają się do tego również wcześniejsze poczynione założenia, przyjęte hipotezy i uprzedzenia, jakie kryją się w umyśle badacza. Ta ostatnia kategoria wydaje się niezwykle istotna w przypadku badania zjawisk politycznych. Loflandowie postulują, aby badacz w trakcie wywiadu przyjął na siebie rolę ucznia, osoby ,niekompetentnej w społecznie aprobowanym stopniu". W sytuacji badania, wywiadu badacz swój subiektywny świat powinien zostawić „za drzwiami” i w największym stopniu skoncentrować się na informacjach przekazywanych przez rozmówcę. Loflandowie wskazują ponadto na proces poszukiwania określonych prawidłowości w przypadku opracowywania danych uzyskanych za pomocą wywiadu. Przy badaniu zjawiska badacz powinien zwracać uwagę na jego: częstotliwość, nasilenie, strukturę, procesy z nim związane, przyczyny oraz konsekwencje. Inaczej mówiąc chodzi o poszukiwanie prawidłowości w obserwowanych przypadkach (L o fl a n d, L o fl and 1995; za: B a b bie 2005: 127-145, 329).

Przy opracowywaniu danych pochodzących z badań jakościowych można zdecydować się na nalizę zorientowaną na zmienną (variable-oriented-analysis) lub analizę zorientowaną na przypadek (case-oriented-analysis). W pierwszej sytuacji odwołujemy się do nomotetycznego wyjaśniania, gdzie za pomocą niewielkiej liczby zmiennych chcemy wyjaśnić pewną ogólną prawidłowość. Osoby biorące udział w badaniu, jak np. radni, są nośnikami określonych zmiennych. W innych okolicznościach mamy do czynienia z wyjaśnieniem idiograficznym, gdzie $\mathrm{w}$ miarę dogłębnej analizie poddajemy każdy odrębny przypadek ( $\mathrm{Hu}$ berman, Miles 1994; za: B abbi e 2005: 401). Jednak do wyprowadzenia ogólnych wniosków konieczna jest przekrojowa analiza przypadków (cross-case analysis), gdzie badacz skupia się na tych zmiennych, które wydały mu się istotne przy pierwszym zdarzeniu. W prowadzonych przeze mnie badaniach można mówić raczej o analizie zorientowanej na zmienną, gdzie zmiennymi byłyby wyodrębnione przeze mnie kategorie analityczne (kody).

Wywiad swobodny ze względu na swą elastyczność i ukierunkowanie na osobiste doświadczenia był, według mnie, najlepszym sposobem dotarcia do informacji weryfikujących stawiane przeze mnie hipotezy. Pozyskiwane informacje podzieliłem na bloki tematyczne uwzględniające charakter sformułowanych przeze mnie założeń. W żaden sposób nie ograniczałem jednak respondentów licząc na to, że w rozmowie pojawią się dodatkowe wątki i informacje weryfikujące i rzucające nowe światło na badane przeze mnie kategorie. Jednym z takich wątków okazał się problem dwuwładzy w województwie, czyli współdziałania w regionie marszałka województwa i wojewody, w sposób bardzo istotny wpływający na postrzeganie przywództwa $\mathrm{w}$ regionie.

Do analizy wywiadów swobodnych z radnymi można zastosować Goffmanowską perspektywę analityczną, a więc metaforę dramaturgiczną odwołującą się do kategorii teatru i sceny ( $\mathrm{G}$ o f fm a n 2000). W trakcie rozmów odniosłem wrażenie, że radni, podobnie jak aktorzy, posługują się scenariuszem swej roli (nie 
chodzi tu o legislacyjne uwarunkowania mandatu radnego, ale raczej tworzone za kulisami wyobrażenie), niekiedy uciekając się do manipulacji i wprowadzając w błąd widza. Widz, jeśli ma możliwość śledzenia gry radnego, najczęściej może to czynić za pośrednictwem mediów. Ja starałem się na to spojrzeć z bliska (w trakcie wywiadów i obserwacji sali obrad). Idąc tropem Ervinga Goffmana, chciałem też zwrócić uwagę na reguły normatywne i pozanormatywne, które decydują o tym, w jaki sposób aktor-radny decyduje się odegrać swoją rolę; na które jej elementy położy największy nacisk, jak wykorzystuje przestrzeń i dekoracje? Bardzo istotny jest tu problem autoprezentacji radnego, tego, w jaki sposób przedstawia się on publiczności i jaką tworzy definicję sytuacji. Problem ten widać m.in. w cytacie:

No opinia publiczna to jest jeszcze coś innego. Znaczy niestety jest tak, że rzeczywista praca radnego, o ile ktoś coś rzeczywiście wnosi, a przebicie się przez media i ocena przez wyborców to są dwie całkiem różne rzeczy [R8].

Warto również odnieść się do jednego z założeń stawianych przez Goffmana, że aktor często odgrywa swą rolę w sposób cyniczny. Manipuluje wrażeniami w celu wywołania pożądanych reakcji u widza - odbiorcy komunikatu. Czy rzeczywiście celem aktora, a w tym przypadku radnego, jest wprowadzenie publiczności w błąd za pomocą manipulacji swoją rolą? I kto w tym przypadku jest publicznością: media, mieszkańcy regionu, inni radni?

Można również zauważyć wśród radnych działania określane przez Goffmana mianem ,idealizacji”. Polegają one na takim prezentowaniu siebie, aby było to zgodne z oficjalnymi i powszechnie uznawanymi wartościami oraz normami w danym społeczeństwie. Konieczne w tym przypadku jest ukrywanie cech, które mogą pozostać w sprzeczności z wzorcowym obrazem, wizerunkiem oczekiwanym przez widzów. Tego typu strategie widoczne są w narracjach, jakimi posługiwali się radni w trakcie wywiadów. Wśród wypowiedzi obecne są swoiste językowe klisze, społecznie akceptowane sposoby dyskursu. Mam tu na myśli takie wypowiedzi, jak:

Ja to traktowałem, może to górnolotnie i przez to nie za dobrze brzmi, ale ja to traktowałem jako dalszą służbę publiczną. Ja to w ten sposób traktuję [R3];

Niemniej jednak, wydaje mi się, że... ja przynajmniej tak rozumuję, że jednak prawdziwy przywódca musi się liczyć z tym, że nie zawsze jego działania budzą podziw i sympatię jego wyborców, ale czasami musi się sporo natrudzić, napocić, żeby przekonać tych ludzi, że decyzje, które w tej chwili podejmuje, są słuszne, mimo że w tej chwili one w jakiś sposób uderzają teraz w część wyborców, to jednak z perspektywy kilkunastu miesięcy czy kilku lat okazuje się, że te decyzje były trafne [R4].

Przed rozpoczęciem wywiadu używałem również standardowych zwrotów, dziękując za poświęcony czas, zwracając uwagę na zapracowanie radnego i mnogość jego obowiązków. Jeszcze raz informowałem o celu badania i gdzie zostaną 
wykorzystane wyniki. Celowo nie mówiłem badanym o anonimowości, gdyż uważałem, że tego warunku nie jestem w stanie spełnić. W trakcie badań starałem się razem z rozmówcą budować pewną nić porozumienia, dlatego chętnie słuchałem o przytaczanych przez moich rozmówców osiągnięciach, sukcesach dotyczących ich dotychczasowej kariery. W rozmowie politycy często odwoływali się do swojego życiorysu. Poszukiwali w nim wydarzeń spoza świata polityki, z dala od życia ich partii, uwiarygadniając $w$ ten sposób siebie jako społeczników, osoby oddane dobru wspólnemu, samorządowców. Trzeba zauważyć, że większość z moich rozmówców nie miało problemów z przywołaniem tego typu wydarzeń. Obserwacja tych strategii uwiarygodnienia siebie jako samorządowca, pozwoliła na stworzenie typologii badanych przeze mnie polityków z uwzględnieniem np. społecznika czy menedżera.

Pozwalałem również badanym na swobodne używanie w pewnych momentach klisz językowych, związanych $\mathrm{z}$ takimi kategoriami, jak dobro wspólne i służba publiczna. Nie starałem się narzucać określonego rytmu wywiadu czy dyscyplinować rozmówców, dlatego że w przypadku polityków (z których większość lubi mówić i robi to całkiem sprawnie) strategia taka wydała mi się bezcelowa. Należy pamiętać, że nawet jeśli uzyskane informacje nie zawsze są przesycone treścią merytoryczną, to uzyskujemy w trakcie tego typu spotkań wiele innych, równie cennych danych. Mówią nam one sporo o badanych środowisku, instytucji i jej aktorach. Nie zawsze (zwłaszcza jeśli wywiad nie ma charakteru standaryzowanego i silnie ustrukturowanego) musimy dążyć do uzyskania w przypadku naszych badanych tych samych, pełnych i wyczerpujących informacji.

Po zakończeniu fazy przeprowadzania wywiadów, która trwała blisko dwa miesiące (maksymalnie udało mi się przeprowadzić dwa wywiady dziennie), dokonana została transkrypcja wywiadów. To żmudny etap, ale konieczny, jeśli chce się skorzystać z techniki analizy treści (zwłaszcza jeśli planujemy posłużenie się analizami konwersacyjnymi). Wielu badaczy uważa, że to jeden z nudniejszych etapów badania. Jest to jednak pogląd zbyt radykalny. Mozolne odsłuchiwanie i przepisywanie dwugodzinnego wywiadu jest męczące, jednak w pewnym sensie „odświeżamy” zebrany przez nas materiał, wyłapujemy - być może nowe, wcześniej niezauważone ważne dla nas - informacje (w tym i błędy, jakie popełniliśmy w naszym badaniu). Warto po zakończeniu wywiadu wynotować swoje własne spostrzeżenia, o których niekoniecznie za tydzień musimy pamiętać. Powinniśmy notować informacje nie tylko związane z miejscem i czasem prowadzonego wywiadu. Ważny jest też kontekst: jak doszło do wywiadu, czy umawialiśmy się telefonicznie, czy osobiście, czy rozmawiamy w budynku urzędu, czy poza siedzibą, czy są to godziny dyżuru radnego, czy czas ten zarezerwowany został dla nas?

Istotne są reakcje w trakcie wywiadu. Obserwując osobę, z którą rozmawiamy, możemy zauważyć, czy na dany temat mówi ona chętnie, czy też nie, w których momentach wycofuje się, czuje dyskomfort, jaki typ pytań pozwala na swobodną wypowiedź badanemu? Są to z pewnością dla większości czytają- 
cych ten tekst truizmy. Warto jednak pamiętać, prowadząc wywiad (zwłaszcza taki, który jest słabo strukturyzowany), aby nie skupiać się wyłącznie na niepomijaniu żadnej z dyspozycji, żadnego przećwiczonego w głowie pytania. Wiele istotnych informacji, wątków, wskazówek, obecnych jest niejako w tle rozmowy - przestrzeni pomiędzy badaczem a badanym. Te notatki, luźne uwagi, nasze spostrzeżenia z pewnością okażą się pomocne przy właściwej „obróbce” zebranego materiału badawczego. W opisywanych badaniach pomogło mi to w zdefiniowaniu różnic między radnymi, którzy po raz pierwszy pełnili mandat radnego, a tymi, którzy funkcjonowali już w samorządzie od przynajmniej dwóch kadencji. Ponadto pozwoliło mi na odtworzenie sieci relacji między radnymi w sejmiku (niekoniecznie pokrywającymi się z granicami klubów), o których nie mógłbym wprost rozmawiać $\mathrm{w}$ trakcie prowadzonych wywiadów.

Poszukiwane informacje zgrupowane zostały w czterech blokach tematycznych: przywództwo i funkcjonowanie sejmiku, podmiotowość regionu, polityka regionalna i rozwój endogeniczny.

Wśród zagadnień dotyczących przywództwa i funkcjonowania sejmiku koncentrowałem się na kilkunastu istotnych dla mnie zagadnieniach. Trudno w tym przypadku operacjonalizować termin przywództwo. To właśnie wywiady z radnymi pomogły mi w ustaleniu jego charakteru. Za punkt wyjścia moich rozważań posłużyły kategorie przywództwa transakcyjnego i transformacyjnego oraz modele przywództwa stosowane w miastach. Interesowało mnie to, w jaki sposób radni doszli do zajmowanych wtedy pozycji społecznych, a precyzując - co zaważyło na ich zaangażowaniu w pracę samorządowca. Starałem się poznać tzw. kanały rekrutacji elit politycznych w regionie, czyli w jaki sposób zaczęła się kariera i działalność radnych w polityce. Jednym z najważniejszych problemów było, czy radni postrzegają siebie jako regionalnych przywódców (czy używają może innych określeń bądź kategorii; czy przywódca polityczny i regionalny ich zdaniem znaczy to samo). Jakie są przyczyny postrzegania siebie lub też nie w tych właśnie kategoriach i jakie cechy powinna posiadać osoba, aby można ją było określać mianem przywódcy politycznego, politycznego lidera? Istotna była również kwestia, na ile nazywanie kogoś przywódcą było efektem postrzegania go w ten sposób przez opinię publiczną. Interesowało mnie również, jak moi rozmówcy patrzą na swoją polityczną przyszłość, czy np. zamierzają być politykami na scenie centralnej. Chciałem dowiedzieć się, czy praca w samorządzie jest etapem na drodze politycznej kariery, czy stanowi coś w rodzaju politycznej szkoły, politycznego treningu. Wiąże się to z kwestią definiowania własnej roli jako radnego sejmiku oraz oceną, jak rolę tę wypełniają inni radni i członkowie zarządu województwa.

Kategoria przywództwa i funkcjonowanie sejmiku wiążą się dla mnie bezpośrednio z zagadnieniami dotyczącymi naszego członkostwa w Unii Europejskiej i spodziewanych w związku z tym zmian i konsekwencji dla rozwoju regionu. W rozmowie $\mathrm{z}$ radnymi interesowała mnie subiektywna wizja radnych, dotycząca najbliższej dekady województwa łódzkiego, to, jak wpływa na przyszłość regionu 
jego obecność w Unii oraz jaki jest stosunek do integracji lokalnych i regionalnych liderów. $\mathrm{W}$ wywiadach pytałem również o stosunek radnych do procesu decentralizacji i rozwiązań w tym kierunku zapisanych w dokumentach rządowych. W badaniu ważne było dotarcie do opinii radnych na temat przyjętego przez rząd kierunku działania oraz relacji pomiędzy dokumentami rządowymi a tymi przygotowywanymi na szczeblu województwa. Chciałem również uzyskać informacje, na ile decyzje radnego w sprawie rozwiązań w zakresie polityki regionalnej wynikają z jego własnych poglądów i przemyśleń, a na ile są to decyzje konsultowane np. z własnym środowiskiem politycznym (partią), czy też organizacjami pozarządowymi, środowiskami naukowymi i biznesowymi. Starałem się również dowiedzieć na ile zagadnienia związane z polityką regionalną są rozwiązywane na forum sejmiku wojewódzkiego i jaka jest w tym zakresie skuteczność tej instytucji, np. jeśli chodzi o prace nad aktualizacją i przygotowaniem strategii rozwoju województwa. W badaniu chodziło również o wyjaśnienie problemu, jak radni oceniają kompetencje sejmiku wojewódzkiego w stosunku do powierzonych samorządowi wojewódzkiemu zadań.

W pytaniach dotyczących kategorii podmiotowości regionu pytałem o oceny sytuacji społeczno-gospodarczej województwa łódzkiego oraz o jego pozycję wśród innych regionów w kraju. Poszukiwałem również informacji na temat tego, czy zdaniem radnych województwo łódzkie posiada w ogóle cechy regionu, do których zaliczyłem: spójność terytorialną, gospodarczą i kulturową, poczucie wspólnotowości mieszkańców, istnienie kolektywnej tożsamości regionalnej. Istotne było dla mnie, czy radni dostrzegają problem kształtowania się tożsamości regionu oraz jakie obszary uznają $\mathrm{w}$ tym procesie za najważniejsze. Zasadniczą kwestią w badaniu była autonomia województwa łódzkiego w zakresie podejmowanych decyzji i regulujące to rozwiązania instytucjonalne.

Z kwestią tą związany jest bezpośrednio problem podziału władzy i kompetencji na linii marszałek województwa i wojewoda. Ważne w badaniu było to, czy można w tym przypadku mówić o tożsamości interesów i wspólnocie działania, czy też raczej należy mówić o konflikcie interesów i rywalizacji tych dwóch instytucji. Wiąże się z tym bowiem problem dwuwładzy w województwie oraz kwestia społecznej percepcji władz wojewódzkich. Istotne było dla mnie, kto zdaniem radnych w świadomości społecznej jest kojarzony z władzami na szczeblu wojewódzkim: instytucje samorządowe i marszałek, czy też reprezentujący rząd wojewoda. Jednym z głównych problemów badawczych była polityka regionalna prowadzona przez Unię Europejską, zwłaszcza jej wpływ na rozwój regionu i jej konsekwencje dla województwa (ekonomiczne, kulturowe, polityczne i społeczne). W badaniu chodziło bowiem o poznanie stanowiska radnych, dotyczącego pożądanego kształtu polityki regionalnej Unii. Ustalenie tego, czy ich zdaniem powinna ona mieć charakter: wspólnotowy, narodowy lub wyłącznie regionalny (odwoływałem się tu zasady subsydiarności). 
Ostatni blok zagadnień dotyczył rozwoju endogenicznego i kapitału społecznego. W pytaniu o kapitał społeczny prezentowałem definicję tego terminu przyjmując, iż jest to zdolność społeczności do samoorganizowania się, chęć uczestniczenia w życiu społecznym i politycznym regionu, prowadzenie aktywnego dialogu $z$ władzami regionu np. poprzez stowarzyszenia i organizacje pozarządowe.

Dokonując analizy materiału badawczego, posłużyłem się techniką kodowania otwartego (B a b b i e 2005: 408), gdyż rezultat moich poszukiwań można przyrównać do mapy pojęciowej. Kody zostały przeze mnie wyodrębnione na podstawie przyjętych w pracy hipotez badawczych oraz na podstawie uzyskanego w wywiadach materiału. Zgodnie z zaleceniami Loflandów w procedurze badawczej koncentrowałem się na poszukiwaniu w badanych przeze mnie przypadkach prawidłowości, takich jak: nasilenie zjawiska, typy i powiązania, kolejność zjawisk oraz przyczyny i konsekwencje (L o fl a n d, L o fla nd 1995).

Prowadzona przeze mnie analiza miała charakter analizy jakościowej, nie są więc ważne stwierdzenia o częstotliwości występowania określonych kategorii lub stwierdzeń, ale to, w jakim kontekście się pojawiają, co rozumieją przez nie moi rozmówcy. Wypowiedzi radnych analizowałem poprzez pryzmat stworzonych przeze mnie kodów, zaznaczając za ich pomocą odpowiednie fragmenty wypowiedzi. Każdy z fragmentów wywiadu może być poddawany kodowaniu wielokrotnie, gdyż nie odnosi się on do jednego kodu, ale można tam odnaleźć również stwierdzenia odnoszące się do innych kategorii.

W badaniu nie przyjąłem dominującej definicji przywódcy. Chciałem odwołać się do istniejących sformułowań, porównując je z otrzymanym w badaniu materiałem. Nie chciałem stworzyć jednego określenia przywództwa, a chodziło mi różnorodną charakterystykę tej kategorii zbudowaną na podstawie wypowiedzi radnych.

Za pomocą uzyskanych informacji chciałem zweryfikować stawiane w koncepcji pracy hipotezy badawcze. Ważna była również dla mnie próba rekonstrukcji przywództwa politycznego w województwie; jego charakteru i cech konstytutywnych. Interesujące było dla mnie to, czy zastosowanie mają teorie zwracające uwagę na istnienie pewnego zespołu cech kojarzonych z przywództwem, których występowanie sprzyja rozpoznaniu w kimś przywódcy i skutecznie odgrywanej przez niego roli lidera. Ponadto chciałem odnieść się do rozróżnienia a przywództwa transakcyjnego i transformacyjnego, próbując ustalić typ przywództwa w badanym przeze mnie przypadku (B u r n s 1995). Jako najwłaściwsze wydało mi się podejście teoretyczne, włączające do analizy przywództwa zmienne kontekstowe i sytuacyjne, czyli charakter władzy samorządowej na szczeblu regionu w Polsce. Za ważne uważałem również założenie, iż przywództwo ma charakter oddolny (jest nadawane, pochodzi od społeczności np. regionalnej, lokalnej) i jest konsekwencją akceptacji grupy, w imieniu której jest sprawowane. Dlatego przywiązywałem również wagę do widoczności (visibility) lidera i jego relacji z otoczeniem 
(wewnętrznym i zewnętrznym). Próba rekonstrukcji charakteru przywództwa była moim zdaniem kluczowa dla ustalenia, czy istnieje spójna wizja rozwoju regionu wśród przywódców politycznych na szczeblu województwa.

Ciekawym problem ujawnionym w trakcie wywiadów była niechęć radnych do określania siebie mianem polityków bądź przywódców politycznych (co sygnalizowałem wyżej). Podobnie unikali określeń, takich jak „uprawianie polityki” lub „działania o charakterze politycznym”. Świadczą o tym wypowiedzi: „Nie jestem politykiem. Nie uważam się za żadnego polityka” [R1]; „Ja się nie uważam za żadnego polityka, tylko po prostu jestem samorządowcem. I tak zawsze mówię [...]. Znam się na sporcie, czy turystyce. Na wielu sprawach się znam" [R2]. W ten sposób rozmówcy starali się dystansować od świata polityki, którego sami byli (są) częścią. W ich przekonaniu zdjęcie z siebie negatywnie społecznie odbieranej etykiety „polityka” uwiarygodnia ich w oczach wyborców, a być może i w oczach samego badacza. Radni często natomiast posługiwali się słowem „samorządowiec”, która to rola w ich przekonaniu jest przeciwstawna kategorii „polityk". Ich zdaniem, przywódca-polityk w odróżnieniu od samorządowca „nie jest zwykłym, normalnym człowiekiem”, ale jest „politycznym zwierzęciem” (choć akurat Arystoteles, piszący o zoon politikon miał, zdaje się, co innego na myśli). Nie spodziewałem się, że określanie siebie mianem polityka (kiedy w gruncie rzeczy jest się nim), może być tak trudne, a moi rozmówcy będą tak dystansować się od tego wymiaru swojej roli.

Charakterystyczny był również język używany przez radnych do opisu sceny politycznej. Nie odbiegał on niekiedy od języka potocznego, języka ulicy, który w sposób emocjonalny i często kategoryczny charakteryzuje środowisko polityków. W wypowiedziach pojawiały się określenia: ,partyjne gry”, ,rozgrywki polityczne”, ,przenoszenie obyczajów z góry” (w domyśle tych złych, z poziomu parlamentu). Zauważalna w wielu wypowiedziach była dychotomiczna wizja świata: dobry samorząd/samorządowiec i zła polityka/polityk na szczeblu centralnym.

Przez cały czas prowadzenia badań nie pozbyłem się jednak uczucia, że dla radnych nie jest to sytuacja łatwa, że postrzegają mnie jako drążącego i próbującego znaleźć słabe punkty ich samych lub ich środowiska politycznego. Dlatego w trakcie badania zdarzały się odmowy udzielenia odpowiedzi na niektóre pytania (zwłaszcza kiedy chodziło o oceny sejmiku i zasiadających w nim radnych). Odmowa ta thumaczona była „lojalnością wobec kolegów” lub stwierdzeniem, że „nie mnie jest oceniać zachowania innych”. W jednym przypadku rozmówca wypowiadał się w tonie bardzo krytycznym o części innych radnych, ale zrobił to off the record, kiedy upewnił się, że wyłączyłem swój dyktafon. Znamienne było dla mnie to, że jeden z radnych poprosił o obecność rzeczniczki sejmiku w trakcie wywiadu, inny zaś rozmówca zgodził się rozmawiać, jeśli w pokoju obecna będzie osoba będąca szefową jego klubu w sejmiku. Świadczy to nie tylko o obawach przed uzewnętrznianiem informacji, ale i pokazuje silnie uwewnętrznioną (w niektórych przypadkach) partyjną lojalność. 
Poziom trudności badania zjawisk z obszaru polityki stopniem trudności nie odbiega zapewne od badania faktów społecznych z innych dziedzin. W dobie mediatyzacji polityki i widoczności medialnej spotykamy się - jako wyborcy i jako badacze - z nowym rodzajem polityków. Są to coraz bardziej świadomi aktorzy społeczni, którzy są przekonani o konieczności stosowania określonych zabiegów komunikacyjnych w celu dotarcia (skutecznego) do odbiorcy. Trudno oczekiwać, że w sytuacji wywiadu, zwłaszcza, gdy rozmówcą jest polityk, relacja przypomina naturalną rozmowę. Tak naturalnie nie jest. Politycy w większości przypadków koncentrują się na prezentowaniu swej publicznej roli włączając informacje ze swego prywatnego życia i dotychczasowej biografii głównie w celu uwiarygodnienia formułowanych tez.

\section{BIBLIOGRAFIA}

B a b b i e Earl (2005), Metody badań społecznych, Wydawnictwo Naukowe PWN, Warszawa.

B e e th a m David (1995), Legitymizacja władzy, [w:] Władza i społeczeństwo, t. 1, J. Szczupaczyński (red.), Wydawnictwo Naukowe Scholar, Warszawa, s. 288-301.

B u r n s James MacGregor (1995), Władza przywódcza, [w:] Władza i społeczeństwo, J. Szczupaczyński (red.), Wydawnictwo Naukowe Scholar, Warszawa, s. 261-273.

C zy żew ski Marek, Kow a lski Sergiusz, P i otrowski Andrzej (red.) (2010), Rytualny chaos, WAiP, Warszawa.

D e n z i n Norman K., L i n c o 1 n Yvonna S. (2010), Wprowadzenie. Dziedzina i praktyka badań jakościowych, [w:] Metody badań jakościowych, t. 1, N. K. Denzin, Y. S Lincoln. (red.), Wydawnictwo Naukowe PWN, Warszawa, s. 19-75.

G o f f m a n Erving (2000), Człowiek w teatrze życia codziennego, Wydawnictwo Aletheia, Kraków.

H a s t r u p Kirsten (1987), The Challenge of the Unreal - or How Anthropology Comes to Terms with Life, „Culture and History”, Vol. 1, s. 50-62.

Hastrup Kirsten (1992), Out of Anthropology: The Anthropologist as an Object of Dramatic Representation, „Cultural Anthropology”, Vol. 7, Issue 3, s. 327-345, doi: 10.1525/ can.1992.7.3.02a00030, 10.10.2011.

H u b e r m a n Michael A., M i 1 e s Matthew B. (1994), Qualitative Data Analysis, Sage Publications, Thousand Oaks (CA).

K v a le Steinar (1996), Interviews: An Introduction to Qualitative Research Interviewing, Sage Publications, Thousand Oaks (CA).

L o fl a nd John, L ofla nd Lyn (1995), Analyzing Social Settings: A Guide to Qualitative Observation and Analysis, International Thomson Publishing, London.

P a tt o n Michael Q. (2002), Qualitative Research and Evaluation Method, Sage Publications, Thousand Oaks (CA)-London.

P r z y b y $\nmid$ o w s k a Ilona (1978), Wywiad swobodny ze standaryzowana lista poszukiwanych informacji i możliwości jego zastosowania w badaniach socjologicznych, „Przegląd Socjologiczny”, vol. 30, (Łódź), s. 53-68.

R e y k ow s k i Janusz (1999), Myślenie polityczne, [w:] Psychologia polityczna, K. Skarżyńska (red.), Wydawnictwo Zysk i S-ka, Poznań, s. 110-138.

$\mathrm{R}$ u b i n Herbert, R u b i n Irene (1997), Jak zdążać do celu nie wiążac sobie rąk. Projektowanie wywiadów jakościowych, [w:] Ewaluacja w edukacji, L. Korporowicz (red.), Wydawnictwo Oficyna Naukowa, Warszawa, s. 201-222. 
S c h u m p e te r Joseph A. (2009), Kapitalizm, socjalizm, demokracja, Wydawnictwo Naukowe PWN, Warszawa.

W y k a Anna (1993), Badacz społeczny wobec doświadczenia, Wydawnictwo IFiS PAN, Warszawa.

\section{Marcin Kotras}

\section{RESEARCHER IN LOCAL GOVERNMENT, THAT IS WHAT WE GET AFTER RESEARCHING POLITICIANS}

This paper concentrates on the problem of using qualitative research methods when we want to carry out researches in political institutions. It indicates important problems connected with politicians interviewing like for example: ethical dilemma, proper questioning and specific context of relation between researcher and politician. It is also an attempt to present politicians from a different perspective with showing and explaining theirs problems of "proper" social role playing. Examples (quotations and described situations) are taken from interviews with members of Łódzkie local government.

Keywords: qualitative research, politics, politicians, local government, interview. 